\title{
Performance Research of China's Listed Commercial Banks Based on Factor Analysis
}

\author{
San.Xing. $\mathrm{He}^{1}$ \\ ${ }^{1}$ School of Three gorges University, Hubei, 443000, China;
}

Keyword: Commercial Bank, factor Analysis, performance evaluation.

\begin{abstract}
Financial firms play a crucial role in the economic development, and commercial banks are important parts in the financial system. Commercial banks' competitiveness is reflected on their business performance. Therefore, measuring the performance of commercial banks has become an urgent task. In this paper, through the establishment of index system, using the factor analysis method of SPSS19.0 software with 11 listed commercial banks' 7 financial indices in 2014, we obtain the 11 listed commercial banks' operating performance ranking in 2014. Finally, we get the evaluation based on the analysis summary of China's commercial banks, aiming to provide reference for investors and bank management decision-making level, at the same time, promoting the steady development of financial market in China.
\end{abstract}

\section{Introduction}

As China's economic system reform deepens gradually, as well as the change of external environment such as China's accession to the WTO, China's commercial banks are facing unprecedented competitive pressure. Improving the management method of commercial banks, building effective performance evaluation system and improving the performance of commercial banks are the key problem for the sustainable development of China's financial sector and are also the basic requirement to the challenge of foreign banks.

As the biggest developing country in the world, China has conducted financial system reform for more than 20 years, and has achieved high grades with great contributions to economic development. At the same time, we realize that although China's banking industry is developing rapidly, it also faces many problems. For example, management efficiency is low, lacking of core competitiveness and non-performing loans ratio is high. These problems seriously weakened the commercial banks in China within the international market competitiveness ${ }^{[1]}$. With the opening of domestic financial market in China, the situation which state-owned commercial banks to unify the whole country has ceased, and the competition between banks is becoming more and more fierce. Moreover, foreign banks whose strengths are relatively strong also begin to enter the Chinese market, accelerating the pace of the banking market competition. In addition, it also has brought unprecedented opportunities and challenges to China's banking industry. In this case, researching on the problem of China's commercial bank performance and finding out a reasonable way of performance evaluation are of great significance.

\section{The Empirical Analysis Of The Performance Evaluation Of China's Listed Commercial Banks}

Selection of samples and indexes.Considering data availability, original sample data of this paper comes from the annual report data of listed commercial banks on financial websites, in newspapers as well as the "China financial yearbook". 11 listed commercial banks in the A-share are finally selected as samples. They are five large commercial banks: Industrial and Commercial Bank of China, China Construction Bank, Agricultural Bank of China, Bank of China, and Bank of Communications. Four joint-stock commercial banks: China Citic Bank, China Merchants Bank, Min Sheng Bank, and Societe Generale. Two city commercial banks: Bank of Beijing and Bank of Nanjing. Chapter 4 of the "Commercial banking law of the People's Republic of China” describes: "commercial banks set security, liquidity and profitability as the management principle ${ }^{[2] " . ~ T h i s ~}$ 
paper considers these three principles comprehensively when selecting indicators of commercial banks and chooses the average total assets return rate (X1), net profit margin (X2), provision for coverage (X3), capital adequacy ratio (X4), core capital adequacy ratio (X5), non-performing loan ratio (X6) and liquidity ratio (X7) as the seven commercial banks' business indicators.

Factor analysis.The basic idea of factor analysis is that according to the size of correlation to group the original variables, making the correlation between variables within the same group is higher, and the correlation between variables in different groups is lower ${ }^{[3]}$. The factor analysis model is described as follows ${ }^{[4]}$ :

(1) $x=(x 1, x 2, \ldots, x p)^{\prime}$ is observable random vector, and the mean vector $E(x)=0$, covariance matrix $\operatorname{cov}(\mathrm{x})=\Sigma$. Moreover, covariance matrices $\Sigma$ and related matrix R are equal;

(2) $F=(F 1, F 2, \ldots, F m)^{\prime}(m<p)$ is immeasurable variables, the mean vector $E(F)=0$, covariance matrix $\operatorname{cov}(\mathrm{F})=\mathrm{I}$, namely each component of vector $\mathrm{F}$ is independent;

(3) $\varepsilon=(\varepsilon 1, \varepsilon 2, \ldots \varepsilon p)^{\prime}$ is independent of $\mathrm{F}$, and $\mathrm{E}(\varepsilon)=0$, the covariance matrix of $\varepsilon \Sigma \varepsilon$ is a diagonal matrix, namely each component of $\varepsilon$ is independent. The following model is called the factor model:

$$
\begin{aligned}
& \mathrm{X} 1=\mathrm{a} 11 \mathrm{~F} 1+\mathrm{a} 12 \mathrm{~F} 2+\ldots+\mathrm{a} 1 \mathrm{mFm}+\varepsilon 1 \\
& \mathrm{X} 2=\mathrm{a} 21 \mathrm{~F} 1+\mathrm{a} 22 \mathrm{~F} 2+\ldots+\mathrm{a} 2 \mathrm{mFm}+\varepsilon 2 \\
& \ldots \ldots \ldots \ldots \\
& \mathrm{Xp}=\mathrm{ap} 1 \mathrm{~F} 1+\mathrm{ap} 2 \mathrm{~F} 2+\ldots+\mathrm{ap} 3 \mathrm{Fm}+\varepsilon p
\end{aligned}
$$

The matrix form of the model is: $\mathrm{X}=\mathrm{AF}+\varepsilon$. Among them, $\mathrm{F}$ is the public factor of $\mathrm{X}$, matrix $\mathrm{A}$ is the loading matrix of factor, and $\varepsilon$ is the special factor for $\mathrm{X}^{[5]}$.

KOM and Bartlett 's sphericity test are provided by the SPSS method, checking whether it is suitable for factor analysis. It is generally believed that if KOM's value is less than 0.5, meaning that it is unfavorable for factor analysis ${ }^{[6]}$, It is feasible to carry out factor analysis through the $\mathrm{KMO}$ and Bartlett's Test as showed in table1. In the table, $\mathrm{KOM}=0.876>0.7$ and Bartlett sphere Test $\mathrm{P}=0.00<0.05$.

Table 1. Kmo and bartlett's.

\begin{tabular}{|l|c|c|}
\hline \multicolumn{2}{|c|}{ Sampling enough degrees of Kaiser-Meyer-Olkin measurements } & 0.876 \\
\hline \multirow{3}{*}{ Bartlett's sphericity test } & The approximate chi-square & 314.278 \\
\cline { 2 - 3 } & $\mathrm{df}$ & 28 \\
\cline { 2 - 3 } & $\mathrm{Sig}$ & 0.000 \\
\hline
\end{tabular}

We can get correlation coefficient matrix's characteristic value, the variance contribution rate and the cumulative contribution rate of the sample through the factor analysis of SPSS ${ }^{[7]}$. The results are shown in table 2 . We select four factors that the cumulated variance contribution ratio of the four factors is $95.054 \%$. Meanwhile, using the maximum variance method to round factor of 25 orthogonal rotations, we can find that factor rotation doesn't change model performance for the data fitting but changes the eigenvalues of factor (table 2). The rotating load matrix is shown in table 3.

Table 2. The total variance of explanation.

\begin{tabular}{|c|c|c|c|c|c|}
\hline \multicolumn{3}{|c|}{ The initial eigenvalue } & \multicolumn{3}{c|}{ Rotate the sum of squares loaded } \\
\hline summation & variance \% & cumulation \% & summation & variance \% & cumulation \% \\
\hline 2.743 & 39.187 & 39.187 & 2.402 & 34.316 & 34.316 \\
\hline 1.910 & 27.281 & 66.468 & 1.826 & 26.080 & 60.396 \\
\hline 1.241 & 17.731 & 84.199 & 1.666 & 22.803 & 83.199 \\
\hline 0.658 & 9.395 & 93.594 & 1.053 & 11.855 & 95.054 \\
\hline 0.322 & 4.603 & 98.198 & & & \\
\hline 0.124 & 1.770 & 99.968 & & & \\
\hline 0.002 & 0.032 & 100.00 & & & \\
\hline
\end{tabular}


The index is divided into four types of common factors. According to the table above , capital adequacy $\mathrm{X} 4$ and core capital adequacy ratio X5 are big load on factor F1, which is called the capital adequacy factor; provision for coverage X3 and non-performing loan ratio X6 are high load on factor F2, which are called the loan safety factor; Average total assets return rate X1 and operating net margin X2 load on factor F3 are very high, which are called the profitability factor; Liquidity ratio X7 loading on factor F4 is very big, which is called the liquidity factor. It can be obtained by factor loading matrix showed in table 4 .

Table 3. The factor loading matrix.

\begin{tabular}{|c|c|c|c|c|}
\hline Factor & F1 & F2 & F3 & F4 \\
\hline Index & 0.309 & -0.123 & 0.740 & 0.156 \\
\hline Average total assets return rate (X1) & -0.013 & 0.156 & 0.932 & -0.118 \\
\hline Operating net margin (X2) & -0.172 & 0.915 & 0.114 & -0.157 \\
\hline Coverage for provision(X3) & 0.968 & -0.121 & 0.025 & 0.114 \\
\hline Capital adequacy (X4) & 0.937 & -0.141 & 0.292 & 0.001 \\
\hline Core capital adequacy ratio (X5) & -0.070 & 0.950 & 0.027 & 0.180 \\
\hline Non-performing loan ratio (X6) & 0.182 & 0.016 & -0.156 & 0.978 \\
\hline Liquidity ratio (X7)
\end{tabular}

$\mathrm{F} 1=0.309 \mathrm{X} 1-0.013 \mathrm{X} 2+\ldots+0.182 \mathrm{X} 7$

$\mathrm{F} 2=0.123 \mathrm{X} 1+0.156 \mathrm{X} 2+\ldots+0.016 \mathrm{X} 7$

$\mathrm{F} 3=0.740 \mathrm{X} 1+0.932 \mathrm{X} 2+\ldots+(-0.156 \times 7)$

$\mathrm{F} 4=0.156 \mathrm{X} 1+(-0.118 \mathrm{X} 2)+\ldots+0.978 \mathrm{X} 7$

Using factor score function of SPSS19.0 to rate four main factors respectively. Factor score coefficient is shown in table 4.

Table 4. The factor score matrix.

\begin{tabular}{|c|c|c|c|c|}
\hline \multirow{2}{*}{ Index } & \multicolumn{4}{|c|}{ Component } \\
\cline { 2 - 5 } & 1 & 2 & 3 & 4 \\
\hline X1 & 0.320 & 0.201 & 0.335 & -0.092 \\
\hline X2 & 0.252 & 0.153 & -0.234 & 0.176 \\
\hline X3 & 0.301 & 0.112 & 0.118 & -0.125 \\
\hline X4 & 0.046 & 0.403 & -0.148 & 0.083 \\
\hline X5 & -0.012 & 0.032 & 0.095 & 0.876 \\
\hline X6 & 0.126 & -0.274 & 0.267 & 0.095 \\
\hline X7 & 0.243 & -0.332 & 0.132 & 0.257 \\
\hline
\end{tabular}

The construction of performance evaluation model of China's listed commercial bank

After naming factor, preliminary model of the performance evaluation of commercial banks is determined according to the variance contribution rate of each factor and the total explained variance ratio:

$\mathrm{FN}=(34.316 * \mathrm{~F} 1+26.080 * \mathrm{~F} 2+22.803 * \mathrm{~F} 3+11.855 * \mathrm{~F} 4) / 95.054$

FN stands for the total score of the performance of commercial Banks ( $N=1,2,3 \cdots 11)$. It can be obtained by table 4 :

Fac1 $=0.320 \mathrm{X} 1+0.252 \mathrm{X} 2+0.320 \mathrm{X} 3+0.046 \mathrm{X} 4-0.012 \mathrm{X} 5+0.126 \mathrm{X} 6+0.243 \mathrm{X} 7$

Fac2 $=0.201 \mathrm{X} 1+0.153 \mathrm{X} 2+0.112 \mathrm{X} 3+0.403 \mathrm{X} 4+0.320 \mathrm{X} 5-0.274 \mathrm{X} 6-0.332 \mathrm{X} 7$

$\mathrm{Fac} 3=0.335 \mathrm{X} 1-0.234 \mathrm{X} 2+0.118 \mathrm{X} 3-0.148 \mathrm{X} 4+0.095 \mathrm{X} 5+0.267 \mathrm{X} 6+0.132 \mathrm{X} 7$

Fac4 =- 0.092 X1 + 0.176 X2-0.125 X3 + 0.083 X4 + 0.876X5 +0.095 X6 + 0.257 X7

Substituting these four formula into the preliminary evaluation model which contains four main factors, we can get the comprehensive evaluation model of 11 listed commercial banks in China:

$\mathrm{F}=0.240 \mathrm{X} 1+0.099 \mathrm{X} 2+0.152 \mathrm{X} 3+0.102 \mathrm{X} 4+0.136 \mathrm{X} 5+0.046 \mathrm{X} 6+0.060 \mathrm{X} 7$ 
We can get total score of the performance of commercial banks after calculation, and rank them according to the order from high to low (table 5 below).

Table 5. The selected samples’ factor score and sorting of commercial bank.

\begin{tabular}{|c|c|c|c|c|c|c|}
\hline Name of Bank & Fac1 & Fac2 & Fac3 & Fac4 & Face5 & Sorting \\
\hline Industrial and Commercial bank & 0.839 & -0.709 & 1.360 & -1.112 & -0.008 & 5 \\
\hline Construction bank & 0.900 & -0.852 & 1.322 & -1.296 & -0.337 & 8 \\
\hline Agricultural bank & 0.532 & -1.622 & -0.373 & -0.454 & -0.706 & 11 \\
\hline Bank of China & 0.101 & -0.927 & 0.502 & -0.433 & -0.056 & 7 \\
\hline Bank of Communications & 0.509 & -1.001 & 0.643 & -1.074 & -0.430 & 10 \\
\hline China citic bank & -0.805 & -0.287 & 0.622 & 1.183 & 0.170 & 4 \\
\hline China merchants bank & -0.339 & 0.573 & -0.024 & -0.534 & -0.046 & 6 \\
\hline Min sheng bank & -0.641 & 0.256 & -0.343 & -1.043 & -0.383 & 9 \\
\hline Societe generale & -0.272 & 1.778 & 0.655 & -0.229 & 0.532 & 2 \\
\hline Bank of Beijing & 0.426 & 0.718 & 0.516 & -0.676 & .335 & 3 \\
\hline Bank of Nanjing & 0.442 & -0.237 & 0.869 & -0.329 & 0.641 & 1 \\
\hline
\end{tabular}

\section{Conclusions}

We can get the following conclusions through the factor analysis of SPSS software by comparing China's 11 A-share listed commercial banks’ operating performance in 2014.

Overall analysis of ranking results.From comprehensive ranking in 2014, the best business performance is the Bank of Nanjing, and the worst is the Agricultural Bank. Among the large commercial banks, the most prominent is the Industrial and Commercial Bank and the worst is the Agricultural Bank. In addition, Bank of China and China Construction Bank have comparable level. Among Joint-stock commercial banks, the best is Societe Generale, and the worst is the Min Sheng Bank, China Citic Bank and China Merchants Bank's performance is medium. Among the two city commercial bank, Nanjing Bank's performance evaluation is very high and it also possesses the best performance of all the selected banks. On the whole, the city commercial Banks operating performance is best, followed by the joint-stock commercial banks, and the large commercial Banks are at last. But there is a big gap between the corresponding single rank and the comprehensive rank of listed commercial banks, meaning that listed commercial banks' unbalanced development in various factors, which affects the overall performance ranking.

According to each factor ranking to analyze the listed commercial banks' performance.

(1) On the capital adequacy factor, Industrial and Commercial Bank, Construction Bank, Agricultural Bank, and Bank of Communications are significantly ahead of other listed commercial banks, Bank of Nanjing and Bank of Beijing are next to these banks, showing that large commercial banks do well in terms of capital adequacy.

(2) On the loan security factor, Societe Generale, Bank of Beijing, China Merchants Bank, Min Sheng Bank respectively rank in the top four, but Agricultural Bank and Bank of Communications come last and the second from bottom. The Agricultural Bank also ranks last in the profitability factor, which leads to its disadvantage position in the total performance evaluation in 2013.

(3) On the profitability factor, Industrial and Commercial bank, Construction Bank and Bank of Nanjing are among the best of listed commercial banks, implying these banks' profitability is 
stronger than others. On the contrary, Industrial and Commercial Bank and China Construction Bank don't have advantages on the loan security.

(4) On the liquidity factor, China Citic Bank ranks first, followed by Societe Generale and Bank of Nanjing. However, Industrial and Commercial Bank, Construction Bank and Bank of Communications perform poorly. This illustrates the large state-owned commercial banks' liquidity is poorer.

As a whole, our country's state-owned commercial bank's performance is poorer than other jointstock banks, mainly because the capital structure of joint-stock commercial bank is more reasonable than the state-owned commercial banks and the operating mechanism is more flexible. So they possess stronger ability of business development. State-owned banks of our country have dual nature goal. On one hand, they hope the investor can maximize, on the other hand, they expect to promote the development of macro economy and maintain social fairness and stability through controlling bank ${ }^{[8]}$. However the general commercial banks' goal is to maximize their own rights and interests.

This paper selects seven operation indices of China's 11 listed commercial banks in 2014 to analyze their performance by using factor analysis of SPSS software, reflecting different degrees of differences on the capital adequacy, loan security, profitability and liquidity among China's large state-owned commercial banks, joint-stock commercial banks and city commercial banks. This makes investors not only pay attention to the comprehensive ranking of the various commercial banks but also analyze each factor variables. This paper also helps in understanding the cause of comprehensive evaluation results in many ways in order to assist investors to make right decisions. In the meantime, the bank managements should also analyze all aspects, only in this way can they improve the competitiveness of the bank.

\section{References}

[1]Guanjun Xia. "Performance valuation of China's commercial banks”[J].Strategy and management, 2004(2):145-149.

[2]Xiaoqun He. "Multivariate statistical analysis" [M].Renmin university of China publishing house, 2008:192-196.

[3]Yu Lu, Xiaofeng Zhang. "Principal component factor analysis method in the application of the performance evaluation of listed banks” [J]. Special zone economy, 2005(10):99-101.

[4]Ji Lin, Yufeng Ji. "Business performance analysis of China's listed commercial banks based on factor analysis ” [J]. economist, 2009(10):8-10.

[5]Ning Wang. "China's listed commercial banks performance analysis-Based on factor analysis and cluster analysis” [J].The financial times, 2012(3):95-97.

[6]Chen Huang. “Commercial banks evaluation research” [M].Beijing:The people’s bank of China research institute, 2002:79-81.

[7]Liqiu Xin. “An empirical analysis of the performance level of China's commercial banks”[J].Contemporary economic, 2013(4):122-123.

[8]Kai Wei, Xuwei Hu. "Research of China's commercial banks’ performance evaluation system ” [J]. Business and management, 2013(2):91-94. 